\title{
PENGARUH PARTISIPASI ANGGARAN, KEJELASAN SASARAN ANGGARAN, DAN KOMITMEN ORGANISASI TERHADAP KINERJA MANAJERIAL
}

(Studi Empiris pada PD BPR BKK Purwokerto)

\author{
Sausan Syifa Qotrunnada*1, Adi Wiratno², Saras Supeno ${ }^{3}$
}

1,2,3 Program Studi Akuntansi, Fakultas Ekonomi dan Bisnis, Universitas Jenderal Soedirman

JL. H.R Boenyamin No. 708 , Purwokerto, Jawa Tengah Indonesia

*Email Correspondence: susanqotrunnada@gmail.com

\begin{abstract}
Absract
This study aims to examine the effect of budgetary participation, budget target clarity and organizational commitment on managerial performance empirical study in PD BPR BKK Purwokerto. To collect data of this study, survey questionnaire with sample selection using purposive sampling method are used. Questionnaires given to 33 managers or managers-equaled level in PD BPR BKK Purwokerto. Their responses are analyzed using multiple linear regression analysis technique through SPSS software. These analysis results reveal that budgetary participation and budget target clarity has significant positive effects to managerial performance. However, organizational commitment does not affect to managerial performance.

Keywords: Budgetary Participation, Budget Target Clarity, Organizational Commitment, Managerial Performance.
\end{abstract}

\begin{abstract}
Abstrak
Penelitian ini bertujuan untuk menguji pengaruh partisipasi anggaran, kejelasan sasaran anggaran, dan komitmen organisasi terhadap kinerja manajerial dengan studi empiris pada PD BPR BKK Purwokerto. Pengumpulan data dalam penelitian ini menggunakan survei kuesioner dengan pemilihan sampel menggunakan metode purposive sampling. Kuesioner dibagikan kepada 33 manajer atau kepala setingkat manajer PD BPR BKK Purwokerto. Data dianalisis menggunakan teknik analisis regresi linear berganda dengan software SPSS. Hasil penelitian ini menunjukan bahwa partisipasi anggaran dan kejelasan sasaran anggaran berpengaruh positif signifikan terhadap kinerja manajerial. Sedangkan omitmen organisasi tidak berpengaruh terhadap kinerja manajerial.
\end{abstract}

Kata Kunci: Partisipasi Anggaran, Kejelasan Sasaran Anggaran, Komitmen Organisasi, Kinerja Manajerial.

\section{PENDAHULUAN}

Pada era globalisasi seperti saat ini perkembangan teknologi dan informasi menjadi sangat pesat dan ilmu pengetahuan menjadi sangat maju. Era ini membuat perusahaan beroperasi pada keadaan yang terus berubah sehingga perusahaan dituntut untuk membuat inovasi-inovasi baru, menetapkan target yang lebih besar dan menjaga citranya di mata para konsumen. Keadaan tersebut juga menuntut perusahaan berkomitmen atas sumber daya alam maupun manusianya sehingga tujuan perusahaan dapat tercapai. Maka dari itu, perusahaan menjadikan anggaran sebagai alat manajemen yang digunakan untuk perencanaan dan pengendalian seluruh kegiatan perusahaan dalam rangka pencapaian tujuan.

Anggaran merupakan suatu rencana yang berlaku untuk periode yang akan datang, disusun secara sistematis yang meliputi seluruh kegiatan perusahaan dan dinyatakan dalam satuan moneter (Lubis, 2014). Anggaran dihasilkan melalui proses yang disebut penganggaran. Walaupun penganggaran merupakan suatu tugas yang bersifat teknis dan dinyatakan dalam istilah keuangan, seluruh teknis yang berkaitan dengan anggaran selalu terdapat peran manusia di dalamnya. Peran manusia yang dimaksud adalah perilaku manusia yang muncul dalam proses 
penyusunan anggaran dan perilaku manusia yang didorong ketika mencoba hidup dengan anggaran (Lubis, 2014).

Partisipasi anggaran mengacu pada keterlibatan seluruh tingkatan manajemen dalam proses penyusunan anggaran yang mengarah pada penentuan tujuan operasional dan penetapan sasaran kinerja perusahaan serta menggunakan input pekerja yang dalam hal ini merupakan manajer, untuk meningkatkan komitmen mereka pada kesuksesan perusahaan. Menurut Anthony dan Govindarajan (2011), partisipasi anggaran merupakan proses penyusunan anggaran yang paling efektif karena mengintegrasikan dua pendekatan dalam proses penyusunannya yaitu topdown dan bottom-up.

Selain itu dengan adanya target anggaran yang jelas dan spesifik akan membuat pelaksana anggaran memberikan reaksi yang positif. Reaksi tersebut adalah peningkatan kepuasan kerja, peningkatan sikap karyawan terhadap anggaran, dan pencapaian kinerja yang lebih baik.Luasnya sasaran anggaran yang dinyatakan secara jelas dan spesifik dan dimengerti oleh pihak yang bertanggung jawab atas pencapaiannya disebut kejelasan sasaran anggaran. Menurut Kenis (1979), kejelasan sasaran anggaran dapat dilihat dari besar atau kecilnya pengaruh dalam merumuskan sasaran anggaran.

Komitmen organisasi juga dapat dihubungkan baik dengan usaha maupun kinerja. Semakin tinggi komitmen karyawan kepada perusahaan mereka, semakin besar usaha yang diberikan karyawan untuk kepentingan perusahaan. Menurut Chong \& Chong (2002), komitmen organisasi juga digunakan sebagai alat bantu psikologis dalam menjalankan organisasi untuk mencapai kinerja yang diharapkan.

Selama ini banyak jurnal penelitian mengungkapkan permasalahan terkait pengaruh partisipasi anggaran, kejelasan sasaran anggaran dan komitmen organisasi terhadap kinerja manajerial. Hasil yang berbeda tersebut mengindikasikan bahwa hubungan pengaruh partisipasi dalam penyusunan anggaran, kejelasan sasaran anggaran dan komitmen organisasi terhadap kinerja manajerial belum dapat disimpulkan secara pasti. Penelitian ini merupakan gabungan dari dua penelitian, yaitu: Yahya et al. (2008) dan Wiprastini et.al (2014). Dimana pada penelitian Yahya et al. (2008) menggunakan variabel partisipasi anggaran sebagai variabel bebas dengan komitmen organisasi dan persepsi inovasi sebagai variabel intervening sedangkan pada penelitian saya komitmen organisasi digunakan sebagai variabel bebas bersama dengan partisipasi anggaran dan kejelasan sasaran anggaran. Dimana variabel kejelasan sasaran anggaran diambil dari penelitian Wiprastini et.al (2014).

Perusahaan dalam penelitian ini mengacu pada Perusahaan Daerah Bank Perkreditan Rakyat Badan Kredit Kecamatan (PD BPR BKK) Purwokerto. Sebagai salah satu instansi pemerintah yang berbentuk Badan Usaha Milik Daerah (BUMD), BPR termasuk dalam kategori penyelenggara pelayanan yang bersifat profit dengan tujuan utamanya yaitu membantu serta 
Pengaruh Partisipasi Anggaran, Kejelasan...

mendorong pertumbuhan perekonomian dan pembangunan daerah di segala bidang sehingga mampu meningkatkan taraf hidup masyarakat serta sebagai salah satu sumber pendapatan daerah. Pada tahun 2014 PD BPR BKK Purwokerto merupakan BUMD di Banyumas dengan aset tertinggi di Jawa Tengah dengan nilai 478 Milyar (www.banyumaskab.go.id). Lalu PD BPR BKK Purwokerto menyumbang pendapatan asli daerah terbesar yaitu Rp 5.182.500.173 pada tahun 2015 dan Rp 6.226.037.700 pada tahun 2016. Prestasi tersebut tentunya tidak dapat tercapai tanpa kinerja yang baik. Kinerja merujuk kepada tingkat keberhasilan dalam melaksanakan tugas serta kemampuan untuk mencapai tujuan yang telah ditetapkan. Kinerja dinyatakan baik dan sukses jika tujuan yang diinginkan dapat tercapai dengan baik (Gibson et al, 1994).

Hal tersebut menarik minat penulis untuk melakukan penelitian dengan studi empiris pada PD BPR BKK Purwokerto dengan tujuan untuk meneliti apakah kinerja PD BPR BKK Purwokerto dipengaruhi oleh peran partisipasi manajer atau kepala setingkat manajer dalam proses penyusunan anggaran yang jelas sehingga mampu meningkatkan kinerjamanajerial manajer atau kepala setingkat manajer PD BPR BKK Purwokerto dan apakah terdapat pengaruh komitmen organisasi terhadap kinerja manajerial. Selain hal tersebut, penelitian mengenai pengaruh partisipasi anggaran, kejelasan sasaran anggaran dan komitmen organisasi terhadap kinerja manajer pada perusahaan BUMD juga belum pernah dilakukan dalam penelitian sebelumnya. Unit analisis dalam penelitian ini menggunakan unit analisis individual yaitu manajer atau kepala setingkat manajer PD BPR BKK Purwokerto.

\section{TINJAUAN PUSTAKA DAN PENGEMBANGAN HIPOTESIS}

\section{Tinjauan Pustaka}

\section{Teori Kebutuhan McClelland (McClelland's Theory of Needs)}

Teori ini dikembangkan pada tahun 1967 oleh David McClelland.Teori kebutuhan McClelland merupakan suatu teori motivasi yang menyatakan bahwa pencapaian, kekuasaan, dan afiliasi adalah tiga kebutuhan yang penting dan dapat membantu menjelaskan tindakan individu dalam konteks manajerial (Robbins dan Judge, 2015).

\section{Kebutuhan Pencapaian (need for achievement)}

Kebutuhan atas prestasi atau achievment adalah suatu istilah yang menunjukkan keinginan individu untuk berprestasi dan menguasai skill serta penggendalian atau standar yang tinggi. Individu dengan kebutuhan prestasi yang tinggi cenderung akan memilih tugas dengan tingkat kesulitan tinggi karena mereka akan merasa tertantang tetapi masih merasa mampu menyelesaikan tugas tersebut.

\section{Kebutuhan Kekuatan (need for power)}

Individu yang memiliki kebutuhan akan kekuasan dapat dibagi menjadi dua tipe, yaitu personal dan institusional. Seseorang yang memiliki tipe kekuasan lembaga atau institusional, akan 
mengoordinir orang lain untuk mau berusahan mencapai tujuan dari organisasi maka dari itu manajaer dengan kebutuhan kekuasaan lembaga yang tinggi akan lebih efektif dibandingkan dengan manajaer dengan kebutuhan kekuasaan personel tinggi.

\section{Kebutuhan Afiliasi (need for affiliation)}

Individu memiliki keinginan untuk mempunyai hubungan persahabatan yang erat dan kooperatif dengan orang lain. Individu yang mempunyai kebutuhan afiliasi yang tinggi cenderung berhasil dalam pekerjaan yang memerlukan interaksi sosial.

\section{Teori Penetapan Tujuan (Goal Setting Theory)}

Teori ini pertama dikemukakan oleh Edwin Locke tahun 1968. Locke menunjukkan adanya keterkaitan antara tujuan dan kinerja seseorang terhadap tugas. Teori penetapan tujuan merupakan suatu teori motivasi yang menjelaskan bahwa tujuan yang spesifik dan sulit, dengan umpan balik, akan mengarahkan pada kinerja yang lebih tinggi (Robbins dan Judge, 2015). Lebih lanjut, Locke dan Latham (1990) menjelaskan bahwa terdapat lima prinsip dalam penetapan tujuan, yaitu:

\section{Kejelasan}

Suatu tujuan harus terukur dengan jelas, tidak ambigu, dan diselesaikan dengan jangka waktu tertentu yang telah ditetapkan.

\section{Menantang}

Tingkat tantangan merupakan salah satu karakteristik yang paling penting dari tujuan. Individu yang memiliki motivasi untuk berprestasi dapat menilai tujuan berdasarkan pentingnya sebuah pencapaian tujuan tersebut. Namun harus ada keseimbangan antara tujuan yang menantang dan tujuan yang realistis.

\section{Komitmen}

Dalam hal ini, gagasan manajemen partisipatif yang terletak pada ide melibatkan seluruh tingkatan manajemen dalam menetapkan tujuan dan membuat keputusan menjadi hal yang penting karena seorang manajaer cenderung memiliki tujuan dan akan lebih berkomitmen jika merasa sebagai bagian dari penciptaan tujuan tersebut. Hal tersebut juga mendorong manajaer untuk mengembangkan tujuan mereka sendiri dan membuat manajaer merasa yakin bahwa tujuan mereka konsisten dengan visi dan tujuan perusahaan.

\section{Umpan Balik (Feedback)}

Umpan balik memberikan kesempatan manajaer untuk mengklarifikasi target, menyesuaikan kesulitan sasaran, dan mendapatkan pengakuan. Memberikan kesempatan kepada individu untuk membuat target merupakan hal yang penting karena individu dapat menentukan sendiri bagaimana tugas mereka akan dikerjakan. 
Pengaruh Partisipasi Anggaran, Kejelasan...

\section{Kompleksitas Tugas}

Dari keempat prinsip di atas dapat ditarik kesimpulan bahwa tujuan yang spesifik dapat meningkatkan kinerja, tujuan yang sulit dicapai namun realistis juga dapat menghasilkan kinerja yang lebih baik dibandingkan dengan tujuan yang tidak terlalu sulit dan bahwa komitmen serta umpan balik akan mengarah pada kinerja yang lebih baik. Terakhir, tujuan yang sulit akan mengarahkan individu untuk menemukan strategi yang dapat membantu individu dalam melaksanakan pekerjaannya agar lebih efektif.

\section{Anggaran}

Menurut Mulyadi (2002), anggaran merupakan suatu rencana kerja yang dinyatakan secara kuantitatif, diukur dalam satuan moneter, mencakup jangka waktu satu tahun dan disusun berdasarkan rencana kegiatan jangka pendek yang ditetapkan dalam proses penyusunan program. Menurut Hansen dan Mowen (2012), anggaran adalah rencana keuangan untuk masa depan yang mengidentifikasikan tujuan dan tindakan yang diperlukan untuk mencapainya. Sementara menurut Anthony dan Govindarajan (2011), anggaran adalah sebuah rencana keuangan, mencakup periode satu tahun dan merupakan alat untuk perencanaan jangka pendek dan pengendalian dalam organisasi.

\section{Partisipasi Anggaran}

Menurut Chong dan Chong (2002), partisipasi anggaran merupakan pemberian kesempatan kepada bawahan untuk terlibat dalam proses penyusunan anggaran dan memiliki pengaruh pada proses tersebut. Definisi senada juga dinyatakan oleh Hansen dan Mowen (2012), yang menyatakan bahwa partisipasi anggaran merupakan pemberian kesempatan kepada manajer tingkat menengah dan bawah untuk terlibat dalam proses penyusunan anggaran. Menurut Anthony dan Govindarajan (2011), partisipasi anggaran merupakan proses penyusunan anggaran yang paling efektif sehingga perusahaan atau organisasi telah mulai menerapkan sistem penyusunan penganggaran ini. Lebih lanjut, Anthony dan Govindarajan (2011) menyatakan bahwa terdapat dua kelebihan dalam partisipasi anggaran yaitu:

Tujuan anggaran akan lebih mudah diterima oleh pelaksana anggaran jika anggaran di bawah pengawasan manajer tingkat atas.

Partisipasi anggaran menciptakan komunikasi yang efektif antara kuasa anggaran dan pelaksana anggaran yang lebih mengetahui produk dan pasar.

\section{Kejelasan Sasaran Anggaran}

Menurut Kenis (1979) memberi definisi kejelasan sasaran anggaran merupakan luasnya sasaran anggaran yang dinyatakan secara jelas dan spesifik dan dimengerti oleh pihak yang bertaggung jawab terhadap pencapaiannya, oleh sebab itu kejelasan sasaran anggaran dapat dilihat dari besar atau kecilnya pengaruh dalam merumuskan sasaran anggaran.Lebih lanjut dikemukakan pula bahwa pelaksanaan anggaran memberi reaksi secara positif dan relatif kuat bila mereka 
merasakan bahwa sasaran anggaran jelas bagi mereka.Reaksi tersebut adalah pengingkatan kepuasan kerja, peningkatan sikap karyawan terhadap anggaran, dan pencapaian kinerja yang lebih baik. Menurut Bulan (2011) tujuan dan sasaran anggaran harus disesuailan dengan lima criteria yaitu: spesifik, terukur, menantang tapi realistis, berorientasi pada hasil akhir, memiliki batas waktu.

\section{Komitmen Organisasi}

Menurut Kohlmeyer et al. (2014), komitmen organisasi merupakan keterikatan emosional individu dengan organisasi sehingga individu sangat berkomitmen, terlibat dan senang terhadap keanggotaan. Komitmen organisasi merupakan sebuah dimensi sikap positif individu dalam suatu organisasi yang dapat dihubungkan dengan kinerja (Kunwaviyah, 2010). Individu di dalam organisasi bersedia mengerjakan apa yang terbaik bagi perusahaannya karena mereka didorong oleh motivasi pribadi mereka dan adanya tekanan-tekanan sosial. Kebanyakan individu mempunyai kepuasan pribadi untuk melaksanakan tugas dengan baik dengan tujuan agar perusahaannya maju. Hal ini yang mendorong motivasi individu di dalam perusahaan untuk melaksanakannya.

\section{Kinerja Manajerial}

Menurut Mahoney et al. (dalam Setiadi, 2013), kinerja manajerial merupakan hasil upaya yang dilakukan manajer dalam melakukan tugas dan fungsinya di dalam organisasi. Sedangkan menurut Mulyadi (2002), kinerja manajerial merupakan hasil kerja yang dapat dicapai oleh seseorang atau sekelompok orang dalam suatu organisasi, sesuai dengan wilayah tanggung jawab dan wewenangnya serta dalam usaha pencapaian tujuan organisasi yang bersifat legal, tidak melanggar hukum, dan sesuai dengan etika dan moral. Menurut Handoko (2012), kinerja manajerial merupakan salah satu faktor penting dalam organisasi karena efektifitas dan tujuan organisasi dapat tercapai melalui kinerja manajerial. Lebih lanjut, Handoko (2012), menyatakan bahwa kinerja manajerial dapat dilihat dari bagaimana seorang manajer menjalankan fungsifungsi manajemen, yaitu perencanaan, investigasi, pengoordinasian, evaluasi, pengawasan, pemilihan staf, negosiasi, dan perwakilan.

\section{Model Penelitian}

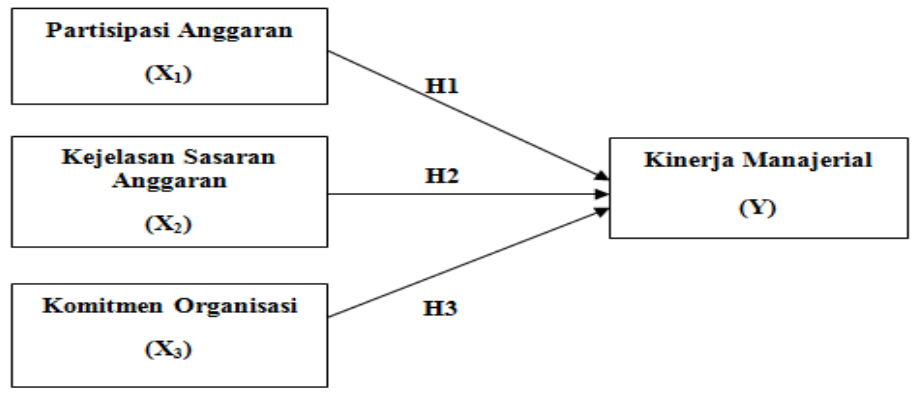

Gambar 2. Model Penelitian 
Pengaruh Partisipasi Anggaran, Kejelasan...

\section{Perumusan Hipotesis}

\section{Pengaruh Partisipasi Anggaran terhadap Kinerja Manajerial di PD BPR BKK Purwokerto}

Hasil penelitian Kewo (2014), Sembiring (2008), dan Yahya et al. (2008) memperoleh bukti bahwa partisipasi anggaran berpengaruh positif dan signifikan terhadap kinerja manajerial. Partisipasi dalam penyusunan dinilai sebagai pendekatan manajerial yang dapat meningkatkan kinerja organisasi. Manajer yang terlibat dalam penyusunan anggaran akan lebih berusaha untuk memahami dan berusaha untuk mencapai tujuan anggaran.

$\mathrm{H}_{1}$ : Partisipasi anggaran berpengaruh positif terhadap kinerja manajerial

Pengaruh Kejelasan Sasaran Anggaran terhadap Kinerja Manajerial di PD BPR BKK Purwokerto

Hasil penelitian Wiprastini et.al (2014), Kewo (2014), dan Sembiring (2008) memperoleh bukti bahwa kejelasan sasaran anggaran berpengaruh positif dan signifikan terhadap kinerja manajerial. Kesempatan individu untuk membuat target yang jelas merupakan hal yang penting karena individu dapat menentukan sendiri bagaimana mereka melakukan tugas. Selanjutnya, dengan pembuatan target yang jelas dan spesifik tersebut diasumsikan akan dapat meningkatkan kinerja kerja.

$\mathrm{H}_{2}$ : Kejelasan sasaran anggaran berpengaruh positif terhadap kinerja manajerial

Pengaruh Komitmen Organisasi terhadap Kinerja Manajerial di PD BPR BKK Purwokerto Hasil penelitian Pramesthiningtyas (2011). Yahya et al. (2008) dan Setyarini (2013) memperoleh bukti bahwa komitmen organisasi berpengaruh positif dan signifikan terhadap kinerja manajerial. Komitmen organisasi mendorong manajer untuk mengembangkan tujuan mereka sendiri dan membuat manajer merasa yakin bahwa tujuan mereka konsisten dengan visi dan tujuan perusahaan. Maka dari itu manajer akan melaksanakan upaya terus menerus demi keberhasilan organisasi yang berdampak pada peningkatan kinerjanya.

$\mathrm{H}_{3}$ : Komitmen organisasi berpengaruh positif terhadap kinerja manajerial.

\section{METODE PENELITIAN}

\section{Jenis Penelitian}

Jenis penelitian yang digunakan dalam penelitian ini adalah penelitian kuantitatif dengan metode survei. Penelitian kuantitatif banyak dituntut untuk menggunakan angka mulai dari pengumpulan data, penafsiran, serta penampilan dari hasilnya.

\section{Objek Penelitian}

Obyek penelitian ini adalah tentang Partisipasi Anggaran, Kejelasan Sasaran Anggaran, Komitmen Organisasi dan Kinerja Manajerial. 


\section{Lokasi Penelitian}

Lokasi yang digunakan dalam penelitian ini adalah PD BPR BKK Purwokerto. Pemilihan PD BPR BKK Purwokerto sebagai tempat penelitian dalam penelitian ini yaitu dikarenakan PD BPR BKK Purwokerto menghasilkan pendapatan asli daerah terbesar di Banyumas, yaitu Rp 5.182.500.173 pada tahun 2015 dan Rp 6.226.037.700 pada tahun 2016.

\section{Populasi dan Sampel Penelitian}

Populasi dalam penelitian ini adalah seluruh manajer atau kepala setingkat manajer PD BPR BKK Purwokerto yaitu kepala bidang, kepala satuan, kepala sub bidang pada BPR BKK Purwokerto kantor pusat dan pimpinan cabang BPR BKK Purwokerto. Sampel dalam penelitian ini dipilih dengan menggunakan metode purposive sampling yang merupakan non-probability sampling di mana sampel dipilih sesuai kriteria sehingga mendukung penelitian. Populasi dalam penelitian ini yaitu manajer atau kepala setingkat manajer yang pernah memiliki pengalaman dalam proses penyusunan anggaran.

\section{Jenis dan Sumber Data}

Data primer diperoleh dengan memberikan daftar pertanyaan yang telah terstruktur atau kuesioner untuk mengumpulkan informasi dari responden. Data sekunder dalam penelitian ini antara lain: pendapatan BUMD di Banyumas pada tahun 2014 yang diperoleh melalui www.banyumaskab.go.id, pendapatan BUMD di Banyumas pada tahun 2015 dan 2016 yang diperoleh melalui Setda Kabupaten Banyumas Bagian Perekonomian, serta data jumlah manajer dan kepala setingkat manajer yang diperoleh melalui Bagian Umum PD BPR BKK Purwokerto.

\section{Metode Pengumpulan Data}

Metode pengumpulan data yang digunakan dalam penelitian ini yaitu metode survei yang bertujuan untuk mengukur perilaku tertentu dari suatu populasi atau sampel dengan menggunakan kuesioner yang dibagikan secara langsung kepada responden di PD BPR BKK Purwokerto.Kuesioner dalam penelitian ini diserahkan langsung kepada responden tanpa melalui perantara dan diambil kembali dalam jangka waktu satu minggu setelah kuesioner dibagikan. Pengukuran variabel bebas ini dilakukan dengan menggunakan skala Likert dengan alternatif jawaban dari satu sampai dengan lima, angka 1 (satu) menyatakan "sangat tidak setuju" dan 5 (lima) menyatakan "sangat setuju". Sedangkan pada variabel terikat menggunakan skala Likert dengan alternatif jawaban dari satu sampai dengan lima, angka 1 (satu) menyatakan "sangat rendah" dan 5 (lima) menyatakan "sangat tinggi". 
Pengaruh Partisipasi Anggaran, Kejelasan...

\section{HASIL DAN PEMBAHASAN}

\section{Gambaran Umum Penelitian}

\section{Gambaran Umum Objek Penelitian}

Kuesioner dibagikan secara langsung kepada responden oleh bagian umum BPR pusat tanpa melalui perantara, dimulai dari tanggal 19 Februari 2018 sampai dengan 26 Februari 2018 yang ditentukan sebagai batas waktu pengembalian dan pengumpulan kuesioner. Dari 33 kuesioner yang dibagikan berdasarkan jumlah unit analisis, sebanyak 19 kuesioner terkumpul sebelum batas waktu pengembalian sedangkan sisanya terkumpul setelah melewati batas waktu pengembalian.Tidak terdapat kuesioner yang tidak kembali dan tidak terdapat kuesioner yang tidak terisi dengan lengkap sehingga jumlah kuesioner yang dapat diolah sebanyak 33 kuesioner.

\section{Gambaran Umum Responden}

Responden dalam penelitian ini adalah manajer dan kepala setingkat manajer PD BPR BKK Purwokerto. Berdasarkan kuesioner yang telah dianalisis didapatkan informasi tentang gambaran umum responden yaitu manajer dan kepala setingkat manajer yang dikelompokkan berdasarkan jenis kelamin, umur, lama bekerja, pengalaman menyusun RKA, dan tingkat pendidikan.

\section{Analisis Data dan Pembahasan}

\section{Uji Validitas dan Reliabilitas}

Uji validitas dalam kuesioner ini menggunakan tingkat signifikansi 95\%, rhitung yang didapat dibandingkan dengan rtabel untuk menentukan validitas kuisioner yang digunakan. Dengan jumlah responden $(n)=33$ dan tingkat probabilitas $5 \%$ serta degree of freedom $(n-2)$ maka diperoleh rtabel sebesar 0,355. Uji reabilitas dalam penelitian ini menggunakan rumus Cronbach Alpha. Suatu instrumen penelitian dinyatakan reliabel jika nilai rhitung > rtabel.

\section{Uji Asumsi Klasik}

\section{Uji Normalitas}

Berdasarkan hasil analisis data, diperoleh nilai Asymp.sig sebesar 0,312 dimana nilai perhitungan tersebut lebih besar daripada $\alpha=0,05$ sehingga dapat disimpulkan bahwa data yang digunakan berdistribusi normal dan layak untuk menggunakan teknik analisis regresi.

\section{Uji Multikolinearitas}

Berdasarkan pergitungan diperoleh nilai tolerancevalue semua variabel diatas 0,10 dan nilai VIF di bawah 10 maka dapat dikatakan tidak terjadi multikolinieritas antar variabel independen.

\section{Uji Heteroskedastisitas}

Berdasarkan hasil pengujian heteroskedastisitas yang diperoleh, nilai sig. dari variabel penelitian ini memiliki nilai $>a(0,05)$ maka dapat disimpulkan bahwa model penelitian ini tidak memiliki gejala heteroskedastisitas. 


\section{Uji Linieritas}

Dari hasil uji linieritas menunjukkan nilai signifikansi uji t dari variabel $\mathrm{Z}_{\mathrm{MWD}}$ adalah 0,081 lebih besar dari nilai $\alpha(0,05)$. Dengan demikian, model dapat menggunakan regresi linier.

\section{Analisis Regresi Berganda}

Berdasarkan pengujian yang telah dilakukan, didapat hasil persamaan sebagai berikut:

$Y=-26,321+1,177 X_{1}+0,684 X_{2}+0,176 X_{3}$

Berdasarkan persamaan tersebut dapat dijelaskan beberapa hal, yaitu:

Nilai konstanta sebesar negatif 26,361 artinya kinerja manajerial akan bernilai negatif 26,361 apabila partisipasi anggaran, kejelasan sasaran anggaran, dan komitmen organisasi bernilai nol atau konstan. Dengan kata lain apabila variabel partisipasi anggaran, kejelasan sasaran anggaran dan komitmen organisasi diasumsikan tidak mengalami perubahan atau sama dengan nol, maka kinerja manajerial akan mengalami penurunan sebesar 26,321 satuan skor.

Koefisien regresi variabel partisipasi anggaran sebesar 1,177 artinya variabel partisipasi anggaran berpengaruh positif terhadap kinerja manajerial. Jika partisipasi anggaran meningkat sebesar satu satuan skor, maka kinerja manajerial PD BPR BKK Purwokerto akan naik sebesar 1,177 satuan skor dengan menganggap variabel lain tetap.

Koefisien regresi variabel kejelasan sasaran anggaran sebesar 0,684 artinya variabel kejelasan sasaran anggaran berpengaruh positif terhadap kinerja manajerial. Jika kejelasan sasaran anggaran meningkat sebesar satu satuan skor, maka kinerja manajerial PD BPR BKK Purwokerto akan naik sebesar 0,684 satuan skor dengan menganggap variabel lain tetap.

Koefisien regresi variabel komitmen organisasi sebesar 0,176 artinya variabel komitmen organisasi berpengaruh positif terhadap kinerja manajerial. Jika komitmen organisasi meningkat sebesar satu satuan skor, maka kinerja manajerial PD BPR BKK Purwokerto akan naik sebesar 0,176 satuan skor dengan menganggap variabel lain tetap.

\section{Koefisien Determinasi}

Koefisien determinasi (R2) digunakan untuk mengetahui keeratan hubungan antara variabel independen dengan variabel dependen. Berdasarkan pengujian yang dilakukan, nilai Adjusted $R$ Square $\left(\mathrm{R}^{2}\right)$ sebesar 0,522. Hal tersebut menunjukkan bahwa sebesar 52,20 persen variasi perubahan variabel kinerja manajerial dalam penelitian ini dapat dijelaskan oleh perubahan variabel partisipasi anggaran, kejelasan sasaran anggaran dan komitmen organisasi, sedangkan 47,80 persen dapat dijelaskan oleh variabel-variabel lain yang tidak diteliti.

\section{Uji Hipotesis}

\section{Pengujian Hipotesis Pertama}

Hasil pengujian hipotesis pertama menunjukkan bahwa hubungan variabel partisipasi anggaran dengan variabel kinerja manajerial memiliki nilai signifikansi sebesar 0,000 dan nilai $t_{\text {hitung }}$ sebesar4,391. Dapat diketahui bahwa nilai $t_{\text {hitung }}(4,391)>t_{\text {tabel }}(1,699)$ atau nilai sig. $(0,000) \leq 0,05$ 
Pengaruh Partisipasi Anggaran, Kejelasan...

yang mengartikan bahwa partisipasi anggaran mempunyai pengaruh yang positif dan signifikan terhadap kinerja manajerial. Dengan demikian, maka hipotesis pertama yang menyatakan bahwa partisipasi anggaran berpengaruh positif terhadap kinerja manajerial, diterima.

\section{Pengujian Hipotesis Kedua}

Hasil pengujian hipotesis kedua menunjukkan bahwa hubungan variabel kejelasan sasaran anggaran dengan variabel kinerja manajerial memiliki nilai signifikansi sebesar 0,043 dan nilai $t_{\text {hitung }}$ sebesar2,120. Dapat diketahui bahwa nilai $t_{\text {hitung }}(2,120)>t_{\text {tabel }}(1,699)$ atau nilai sig. $(0,043)$ $\leq 0,05$ yang mengartikan bahwa kejelasan sasaran anggaran mempunyai pengaruh yang positif dan signifikan terhadap kinerja manajerial. Dengan demikian, maka hipotesis kedua diterima.

\section{Pengujian Hipotesis Ketiga}

Hasil pengujian hipotesis ketiga menunjukkan bahwa hubungan variabel komitmen organisasi dengan variabel kinerja manajerial memiliki nilai signifikansi sebesar 0,541 dan nilai thitung sebesar0,619. Dapat diketahui bahwa nilai $t_{\text {hitung }}(0,619)<t_{\text {tabel }}(1,699)$ atau nilai sig. $(0,541) \geq 0,05$ yang mengartikan bahwa komitmen organisasi tidak berpengaruh terhadap kinerja manajerial. Dengan demikian, maka hipotesis ketiga ditolak.

\section{KESIMPULAN DAN IMPLIKASI}

\section{Kesimpulan}

Berdasarkan hasil penelitian dan pembahasan, dapat diperoleh kesimpulan sebagai berikut: (1) Partisipasi anggaran berpengaruh positif dan signifikan terhadap kinerja manajerial PD BPR BKK Purwokerto. (2) Kejelasan sasaran anggaran berpengaruh positif dan signifikan terhadap kinerja manajerial PD BPR BKK Purwokerto. (3) Komitmen organisasi tidak berpengaruh terhadap kinerja manajerial PD BPR BKK Purwokerto.

\section{Implikasi}

Rekomendasi atau implikasi dari penelitian ini yaitu PD BPR BKK Purwokerto perlu mempertahankan dan mengoptimalkan kebijakan anggaran partisipatif karena terbukti memberikan pengaruh positif terhadap kinerja manajerial. Selain itu PD BPR BKK Purwokerto perlu mempertimbangkan untuk menciptakan lingkungan kantor yang baik serta pemberian insentif kerja menurut beban kerja masing-masing manajer, karena pemberian insentif diluar gaji yang sesuai dengan porsi akan meningkatkan kinerja manajer.

\section{Keterbatasan}

Pengumpulan kuesioner dalam penelitian ini memerlukan waktu yang lama. Hal tersebut disebabkan karena kesibukan responden dalam melaksanakan tugasnya sebagai manajer maupun kepala setingkat manajer sehingga tidak dapat mengisi kuesioner dalam waktu yang telah ditentukan. 


\section{DAFTAR PUSTAKA}

Anthony, R.N. dan Govindarajan V. (2011). Management Control System (Sistem Pengendalian Manajemen).Edisi 11. Jakarta: Salemba Empat.

Bulan, R.F. (2011). Pengaruh Partisipasi Anggaran dan Kejelasan Sasaran Anggaran terhadap Job Relevant Information serta Implikasinya pada Senjangan Anggaran.Vol 4 No. 1. Januari: 3350.

Chong, V. K. dan Chong, K. M. (2002). Budget Goal Commitment and Informational Effects of Budget Participation on Performance : A Structural Equation Modeling Approach. Behavioral Research in Accounting.Vol.14, No.1.

Ghozali, I. (2009). Ekonometrika Teori, Konsep dan Aplikasi dengan SPSS 17. Semarang: Badan Penerbit Universitas Diponegoro.

Handoko, H.T. (2012). Manajemen.Edisi 2. Yogyakarta: BPFE Yogyakarta.

Hansen, D. R. dan Mowen, M. M. (2012). Managerial Accounting (Akuntansi Manajemen).Edisi 8. Jakarta: Salemba Empat.

Ikhsan, Arfan dan Ishak Muhammad. (2005). Akuntansi Keprilakuan. Jakarta: Salemba Empat.

Kewo, C.L. (2014). Pengaruh penganggaran partisipatif, kejelasan sasaran anggaran dan implementasi pengendalian intern terhadap kinerja manajerial, studi pada pemerintah kabupaten/kota di Provinsi Sulawesi Utara. Tesis. Universitas Padjajaran: Bandung.

Kohlmeyer III, James, Mahenthiran, S., Parker, R. J., Sincich, T. (2014). "Leadership Budget Participation, Budgetary Faireness and Organizational Commtiment".Advances in Accounting Behavioral Research. Vol. 17, h. 95-118.

Kunwaviyah, N. (2010). "Peran Variabel Komitmen Organisasi dan Inovasi Pada Hubungan Penganggaran Dan Kinerja: Studi Kasus Pada SKPD Kabupaten Magelang". Jurnal Akuntansi \& Auditing. Vol.7, h. 33-48.

Kurnia, R. (2010). Pengaruh budgetary goal characteristics terhadap kinerja managerial dengan budaya paternalistik dan komitmen organisasi sebagai moderating variabel. Vol 2.No. 2. Desember: 54-72.

Leach-López, M. A., Stammerjohan, W. W., dan Lee, K. S. (2009).“Budget Participation and Job Performance of South Korean Managers Mediated by Job Satisfaction and Job-Relevant Information".Management Research News.Vol.32, No. 3, h. 220-38.

Lubis, A. I. (2014). Akuntansi Keperilakuan. Edisi 2. Jakarta: Salemba Empat.

M. Nafarin. (2007). Penganggaran Perusahaan. Edisi 3. Jakarta: Salemba Empat.

Mas'ud, F. (2004). Survai Diagnosis Organisasional Konsep \& Aplikasi. Semarang: Badan Penerbit Universitas Diponegoro.

Mulyadi. (2002). Akuntansi Manajemen: Konsep Manfaat dan Rekayasa. Edisi 3. Jakarta: Salemba Empat.

Nengsy, H., Sari, R. dan Restu, A. (2013). "Pengaruh Partisipasi Penyusunan Anggaran Terhadap Kinerja Manajerial Dengan Job-Relevant Information, Kepuasan Kerja dan Motivasi Sebagai Variabel Intervening". Jurnal Akuntansi. Vol. 2, No. 1, h. 1-17.

Nouri, H. dan Parker, R .J. (1998). The Relationship Between Budget Participation and Job Performance: The Roles of Budget Adequacy and Organizational Commitment.Accounting, Organizations and Society, 23-5/6: 467-483.

Pramesthiningtyas, A. H. (2011). "Pengaruh Partisipasi Anggaran terhadap Kinerja Manajerial melalui Komitmen Organisasi dan Motivasi sebagai Variabel Intervening".Skripsi. Universitas Diponegoro.

Primadana, G. H. M., Yuniarta, G. A., AK, S., Adiputra, I. M. P., \& Si, M. (2014). Pengaruh Partisipasi Dalam Penyusunan Anggaran, Kejelasan Sasaran Anggaran Dan Struktur Desentralisasi Terhadap Kinerja Manajerial Skpd Dengan Pengawasan Internal Sebagai Variabel Pemoderasi (Studi Empiris Pada Pemerintah Kabupaten Badung). JIMAT (Jurnal Ilmiah Mahasiswa Akuntansi S1), 2(1).

Ramandei, P. (2010). Karakteristik Sasaran Anggaran, Sistem Pengendalian Intern dan Kinerja Manajerial Aparat Pemerintah Daerah. MAKSI, 10(1). 
Robbins, S. P. dan Judge, T. A. (2015). Perilaku Organisasi (Organizational Behavior).Edisi 16. Jakarta: Salemba Empat.

Rudianto. (2013). Penganggaran. Jakarta: Erlangga.

Sekaran, Uma. (2011). Research Methods For Business. Edisi I and 2. Jakarta: Salemba Empat.

Sekaran, U. dan Bougie, R. (2010). Research Methods for Business: A Skill Building Approach. London: John Wiley and Sons Inc.

Sembiring, S. A. T. (2008). Pengaruh Partisipasi Anggaran Dan Kejelasan Sasaran Anggaran Terhadap Kinerja Manajerial Dengan Motivasi Sebagai Variabel Intervening pada Kawasan Industri Medan (Master's thesis).

Setiadi, H. (2013). "Pengaruh Partisipasi Anggaran terhadap Kinerja Manajerial dengan Komitmen Organisasi dan Budget Emphasis sebagai Variabel Intervening: Studi Kasus pada SKPD Pemerintah Kabupaten Boyolali)". Skripsi. Universitas Diponegoro.

Setyarini, M. N. (2013). Pengaruh Partisipasi Anggaran Terhadap Kinerja Manajerial Dengan Komitmen Organisasi Sebagai Variabel Intervening Pada Bank Perkreditan Rakyat (Doctoral dissertation, UAJY).

Sidiq, A. (2009). Pengaruh Komitmen Organisasi dan Keinginan Sosial terhadapKinerja Manajerial Melalui Partisipasi Anggaran (Studi Kasus pada PT. OrindoAlam Ayu Indonesia, Jakarta). Skripsi Fakultas Ekonomi Universitas Jember.

Sinambela, E. (2003). Pengaruh partisipasi dalam Penyusunan Anggaran terhadap Kinerja Manajerial.Tesis S2 Program Pasca Sarjana. Universitas Sumatera Utara. Medan Sinuraya.

Sugiyono. (2012). Metodologi Penelitian Bisnis. Alfabeta: Bandung.

Suliyanto, D. (2011). Ekonometrika Terapan: Teori dan Aplikasi dengan SPSS. Penerbit Andi, Yogyakarta.

Wiprastini, I. G. A. K. Y., Sinarwati, N. K., Herawati, N. T., \& AK, S. (2014). Pengaruh Kejelasan Sasaran Anggaran Terhadap Kinerja Manajerial Dengan Desentralisasi Dan Ketidakpastian Lingkungan Sebagai Variabel Pemoderasi (Studi Empiris Pada 15 SKPD Berupa Dinas Di Kabupaten Buleleng). JIMAT (Jurnal Ilmiah Mahasiswa Akuntansi S1), 2(1).

Yahya, M. N., Ahmad, Nik N. N., dan Fatima, A. H. (2008). "Budgetary Participation and Performance : Some Malaysian Evidence”. International Journal of Public Sector Management. Vol. 21, No. 6, h. 58-73.

Website :

https://www.banyumaskab.go.id/read/16491/bumd-di-banyumas-hasilkan-laba-2285-

m\#.Ws6UkzO-nIV, diakses 13 Oktober 2017 